\title{
Safety and Physicochemical Activities of Allium Hookeri
}

Ji-Yun Kim ${ }^{1}$, Ae-Jung Kim², Min-Ju Kim²*

${ }^{1}$ Department of Alternative Medicine, Kyonggi University, Seoul, Korea

${ }^{2}$ Department of Nutrition Therapy, The Graduate School of Alternative Medicine, Kyonggi University, Seoul, Korea

\author{
*Corresponding author: Min-Ju Kim, \\ Department of Nutrition Therapy, The \\ Graduate School of Alternative Medicine, \\ Kyonggi University, 63, Kyonggidae-ro-9 gil, \\ Seodaemun-gu, Seoul 03752 Korea \\ Tel.: +82 23905012 \\ Fax: +825042461464 \\ Email: camdr@naver.com
}

Received November 4, 2019

Revised December 13, 2019

Accepted December 17, 2019

Published December 30, 2019

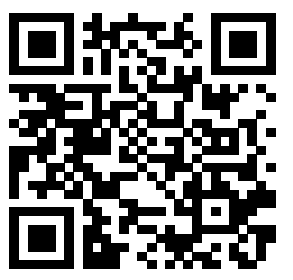

\begin{abstract}
Purpose: The aim of this study was to evaluate the physicochemical activities and safety of extracts of Allium hookeri (A. hookeri). Methods: MTT assays of $A$. hookeri extracts (leaf and root, DW and $\mathrm{EtOH}$ ) were conducted for evaluation of safety. With regard to physicochemical activity of general composition components, sulfur compounds (leaf and root, raw), anti-inflammatory effects, and antioxidant activity (leaf and root, DW and EtOH) were analyzed, and we tested whether there was any correlation between physicochemical substances and free radical scavenging activities (DPPH and ABTS). Results: In the MTT assay, the cell survival rate was $>97 \%$ at concentrations of 50,100 , and $200 \mu \mathrm{g} / \mathrm{mL}$ of $A$. hookeri extracts, indicating that they were safe. All general composition components except for carbohydrate in raw leaf of $A$. hookeri were higher than in raw root, while sulfur level was highest in raw root. NO inhibitory effect of EtOH root extract was the highest. The DPPH and ABTS radical scavenging activities of EtOH leaf extract were the highest. Conclusion: Physicochemical substance activities (total polyphenol, total flavonoid, and sulfur) were correlated with free radical scavenging activity (DPPH and ABTS) resulting in suppression of NO production that enhances free radical scavenging activity.
\end{abstract}

Keywords: Allium hookeri, Sulfur, MTT assay, Antioxidant activity, NO production

\section{Introduction}

최근 우리나라는 영양과잉과 운동부족, 정신적 스트레스 증가 등으로 만성대사증후군이 급격히 증가하고 있는 실정이다(Min et al., 2011; Ahn et al., 2016). 게다가 산업화로 증가된 각종 환 경오염 물질로 인해 생성된 reactive oxygen species (ROS)는 체 내에서 염증반응을 촉진시켜 노화와 만성질환 발생의 원인으로 작 용하여(Hong, 2009; Ji \& Park, 2011) 건강상의 위해를 가중시 키고 있다(Choi \& Kim, 2014). 이에 만성대사증후군을 예방하거 나 억제시키는데 도움이 되는 생리활성물질에 대한 연구가 활발히 진행되고 있다(Masaki et al., 1995; Ham et al., 2017).

$\mathrm{ROS}$ 의 위해로부터 생체를 보호하는 항산화시스템은 채소와 과 일과 같은 천연물에 많이 함유되어 있는 항산화제를 섭취로 강화 될 수 있다. 한동안 가시광선과 자외선에 의해 쉽게 파괴되는 천 연 항산화제(Yun et al., 2018) 대신 합성항산화제가 많이 사용되 었으나, 합성항산화제의 부작용이 차츰 밝혀지면서 안전한 천연 물에 대한 관심이 증가되고 있다(Lee et al., 2008, Kim et al.,
2019).

뿌리와 맛이 인삼과 닮아 삼채(Allium hookeri)라고 불리는 백 합과 식물로 중국에서는 3,000 여 년 전부터 식·약용으로 이용해 왔으며, 인도의 갠지스 강의 삼림지역과, 부탄, 스리랑카, 미얀마, 히말라야 등 해발 $1,400-4,200 \mathrm{~m}$ 의 고산지대에서 주로 자생하 는데, 쓴맛, 단맛, 매운맛 3 가지 맛이 나며, 모든 부위가 식용 가 능하다(Ayam, 2011; Choe \& Choe, 2014).

삼채의 효능은 식이유황에서 기인한다는 보고가 있는데(Park \& Yoon, 2014; Bae \& Bae, 2012), 마늘의 6배 정도의 식이유황 을 함유하고 있다(Kim et al., 2012). 식이유황은 염증반응을 감 소시키고 살균력이 강해 통증 완화, 아토피, 건선, 무좀 등과 같 은 피부질환 및 숙취해소 등에도 효과가 뛰어나다(Won et al., 2013). 또한 S-allylcysteine을 포함하는유황 유기화합물들은 노 화 관련 증상 완화와 세포막의 지질산화와 프리라디칼의 생성을 저해하는 것으로 알려져 있다(Hagenman et al., 1997).

이와 같은 효능을 지닌 삼채는 이용가치가 뛰어남에도 불구하 고(Cheon et al., 2016) 국내에서는 아직까지 잘 알려져 있지 않 
은 식용채소로 그 생리활성 연구도 미비한 실정이다.

따라서 본 연구에서는 국내에서 식용이나 화장품 소재로의 활 용도가 높아질 것으로 예상되는 삼채를 부위별(잎과 뿌리), 용매 별로 구분하여 그 안전성 및 생리활성을 알아보고자 하였다.

\section{Methods}

\section{1. 실험재료}

본 연구에서 사용된 삼채는 강원도 대관령 삼채농장 (Gangwon-do, Korea)에서 2017년 11월에 수확한 삼채를 구입 후 잎과 뿌리를 분리하여 흐르는 물에 수세한 다음 거즈로 물기를 제거한 후 일반성분과 황 함량 분석용 시료로 사용하였다.

세척된 삼채의 잎과 뿌리는 동결건조기(freeze dryer, PVTFD 10R; Ilsinbiobase, Korea)에서 $48 \mathrm{~h}$ 동안 동결시킨 후 분쇄 (Mixer HM-5000; Hyun Dae Household Appliances, Korea) 하여 40 mesh 체에 통과 시켜 분말화 하여 냉장 보관하면서 안전 성과 생리활성 측정용 시료로 사용하였다.

\section{2. 일반성분 분석}

삼채 잎과 뿌리의 일반성분은 Horwitz \& Latimer (2005)에 준 하여 분석하였다. 수분 함량은 $105^{\circ} \mathrm{C}$ 상압가열건조법, 조회분은 $550^{\circ} \mathrm{C}$ 전기 회화로를 이용한 직접 회화법, 조지방은 Soxhlet 추 출법, 조단백질 함량은 질소분석기(Vario $\operatorname{Max} \mathrm{C} / \mathrm{N}$; Elementer Co. Ltd., Germany)로 분석하였다. 탄수화물 함량은 샘플 $100 \mathrm{~g}$ 중에서 수분, 조단백질, 조지방 및 조회분 함량을 감한 값으로 산 출하였다.

\section{3. 황 함량 분석}

삼채 잎과 뿌리의 황 함량은 습식분해 후 유도 결합 플라즈 마 분광 분석기(Inductively Coupled Plasma, Lactam 8440 Plasmalac; Longjumeau Cedex, France)를 이용하여 황(sulfur) 함량을 측정하였다.

\section{4. 안전성 및 생리활성 측정}

1) 열수 추출물 제조

동결건조 한 삼채 잎과 뿌리 분말은 각각 $500 \mathrm{~mL}$ 증류수 에 $10 \mathrm{~g}$ 씩 넣어 가열 환류추출기(HEATING MANTLE, MSEAM920400, Korea)를 이용하여 $2 \mathrm{~h}$ 동안 추출한 후, 여과(No. 2 , Whatman, England)한 다음 여액을 $30 \mathrm{~mL}$ 까지 감압 농축 (N-1110; EYELA, Japan)한 후 freezing dryer (FD5808; Ilshinbiobase, Korea)에서 건조 시킨 분말을 냉동 보관하면서 사 용하였다.

\section{2) 에탄올 추출물 제조}

동결건조 한 삼채 잎과 뿌리 분말을 각각 $500 \mathrm{~mL} 99 \%(\mathrm{~V} / \mathrm{V})$ 에탄올에 $10 \mathrm{~g}$ 씩 넣어 상온에서 $72 \mathrm{~h}$ 동안 방치 후, 여과(No. 2, Whatman)한 다음 여액을 진공감압농축기 $(\mathrm{N}-1110$; EYELA, Japan)로 $30 \mathrm{~mL}$ 까지 농축 한 후 freezing dryer (FD5808, Ilshinbiobase)에서 건조 시킨 분말을 냉동 보관하면서 사용하였 다.

\section{3) 세포 배양}

RAW 264.7 대식세포는 American Type Culture Collection (ATCC; Manassas, USA)에서 동결상태로 구입하였다. RAW 264.7 대식세포는 10\% (V/V) FBS, penicillin (100 unit/mL)과 streptomycin sulfate $(100 \mu \mathrm{g} / \mathrm{mL})$ 가 함유된 DMEM 배지에서 $37^{\circ} \mathrm{C}, 5 \% \mathrm{CO}_{2}$ 조건으로 Incubator (Thermo Fisher Scientific, USA)에서 배양하였다.

\section{4) MTT assay}

삼채 잎과 뿌리 용매별(열수, 에탄올) 추출물 시료의 세포독 성 측정을 위해 RAW 264.7 cell을 96 well plate에 $5.0 \times 10^{4}$ cells/well로 동일하게 분주하고 $24 \mathrm{~h}$ 동안 배양한 후, 기존의 배지를 제거하고 새로운 배지를 넣은 뒤, dimethyl sulfoxide (DMSO; Daejung, Korea)에 녹인 각각의 시료를 다양한 농도 (50, 100, $200 \mu \mathrm{g} / \mathrm{mL}$ 로 Dulbecco's Modified Eagle Medium (DMEM)에 희석하여 첨가하였다. $\mathrm{DMSO}$ 의 처리 농도는 배지 대 비 $0.1 \%$ 이하가 되도록 하였다. 이를 다시 $37^{\circ} \mathrm{C}, 5 \% \mathrm{CO}_{2}$ 조건 으로 humidified incubator에 $24 \mathrm{~h}$ 배양하였다. 상층 액을 제 거하고 $1 \mu \mathrm{g} / \mathrm{mL}$ 의 3-(4,5-dimethylthiazol-2-yl)-2,5Diphenyltetra-zolium bromide (MTT; Invirtrogen, USA)를 각 well에 첨가한 뒤 $4 \mathrm{~h}$ 동안 반응시켰다.

반응 후 MTT 용액을 제거하고 $\mathrm{DMSO}$ 를 $150 \mu \mathrm{L} /$ well에 분주 하여 formazan crystal을 용해시킨 뒤 ELISA microplate reader (Infinite M200 pro; Männedorf Switzerland)에서 $540 \mathrm{~nm}$ 에서 흡광도를 측정하여 대조군에 대한 세포 생존율을 백분율 $(\%)$ 로 나 타내었다.

\section{5) NO 생성량 측정}

삼채 잎과 뿌리 용매별(열수, 에탄올) 추출물 시료에 대한 $\mathrm{NO}$ 함량측정을 위해 $\mathrm{NO}$ 산화물인 $\mathrm{NO}_{2}$ (nitrite)를 Griss 반응을 이용 하여 측정하였다. RAW 264.7 세포를 24 well plate의 각 well에 $1.5 \times 10^{6}$ cells/well이 되도록 분주하고 $24 \mathrm{~h}$ 후에 $500 \mathrm{ng} / \mathrm{mL}$ 의 lipopolysaccharide (LPS; Sigma-Adrich, USA) 및 각 시료 의 최종농도가 $50-200 \mu \mathrm{g} / \mathrm{mL}$ 가 되도록 조정하여 첨가한 다음 $37^{\circ} \mathrm{C}, 5 \% \mathrm{CO}_{2}$ 조건으로 $24 \mathrm{~h}$ 배양하였다.

배양된 RAW 264.7 세포를 $0.1 \mathrm{~mL}$ 씩 96 well plate에 넣고 
여기에 Griess 시약(Sigma-Aldrich)을 같은 양을 첨가하여 10 $\min$ 반응시킨 후, $540 \mathrm{~nm}$ 에서 흡광도를 측정하였다.

\section{6) 항산화능 측정}

삼채 잎과 뿌리 용매별(열수, 에탄올) 추출물 시료의 총 페놀함 량은 Folin-Denis의 방법을 변형하여 측정하였다(Jung et al., 2019). 즉, 추출물 $1 \mathrm{~mL}$ 을 취하여 $2 \%(\mathrm{w} / \mathrm{v}) \mathrm{Na}_{2} \mathrm{CO}_{3}$ 용액 $1 \mathrm{~mL}$ 를 가한 후 $3 \mathrm{~min}$ 실온의 암소에서 방치하였고, $50 \%(\mathrm{v} / \mathrm{v})$ FolinCiocalteu 시약 $0.2 \mathrm{~mL}$ 를 가하여 반응시킨 다음 $750 \mathrm{~nm}$ 에서 흡 광도를 측정하였다. 총 페놀 함량은 tannic acid를 이용하여 작성 한 표준곡선을 바탕으로 tannic acid로 환산하여 나타내었다.

총 플라보노이드 함량은 Davis(1947)법을 변형한 방법에 따 라 측정하였다. 추출물 $400 \mathrm{~mL}$ 에 Diethylene glycol $4 \mathrm{~mL}$ 와 1 $\mathrm{N} \mathrm{NaOH} 40 \mathrm{~mL}$ 를 첨가한 후 $37^{\circ} \mathrm{C}$ 에서 $1 \mathrm{~h}$ 반응 시킨 다음 420 $\mathrm{nm}$ 에서 흡광도를 측정하였다. 총 폴라보노이드 함량은 rutin을 이용하여 작성한 표준곡선을 바탕으로 rutin으로 환산하여 나타 내었다.

1,1-diphenyl-2-picrylhy drazyl (DPPH; Sigma-Aldrich) radical 소거능은 시료 $100 \mu \mathrm{L}$ 에 $1.5 \times 10^{-4} \mathrm{M} \mathrm{DPPH}$ 용액 100 $\mu \mathrm{L}$ 를 첨가한 후 $30 \mathrm{~min}$ 실온에 방치하여 $517 \mathrm{~nm}$ 에서 흡광도를 측정하였다(Naik et al., 2004).

ABTS radical 소거능은 Fellegrini et al.(1999)의 방법을 변 형하여 측정하였다. $7 \mathrm{mM} \mathrm{2,2'azino-bis-3-ethylbenzo-}$ thiazoline-6-sulfonic acid (ABTS; Sigma-Aldrich)와 2.45 $\mathrm{mM}$ potassium persulfate를 같은 농도로 혼합한 것을 실온의 암 소에서 $24 \mathrm{~h}$ 방치하여 ABTS radical을 형성시킨 다음 $732 \mathrm{~nm}$ 에 서 흡광도 값이 0.70 이 되도록 $\mathrm{PBS}(\mathrm{pH} 7.4)$ 용액으로 희석 후 희석된 $\mathrm{ABTS}$ 용액 $190 \mu \mathrm{L}$ 에 시료 $10 \mu \mathrm{L}$ 를 가하여 $10 \mathrm{~min}$ 반응 시킨 용액의 흡광도를 $732 \mathrm{~nm}$ 에서 측정하였다.

\section{5. 통계처리}

실험 자료의 분석은 SPSS program(SPSS 24.0, SPSS Institute, IL, USA)을 이용하여 평균과 표준편차를 구하였다. 두 변수간의 차이는 Student's t-test를 실시하였고, 독립변수 요인 이 3개 이상인 경우 one-way ANOVA를 실시한 후, Duncan's multiple range test로 각 시료의 평균차에 대한 사후 검정은 $p<0.05$ 의 유의수준에서 실시하였다.

\section{Results and Discussion}

\section{1. 일반성분}

삼채의 잎과 뿌리의 일반성분 함량을 분석한 결과는 Table 1 에 나타내었다.

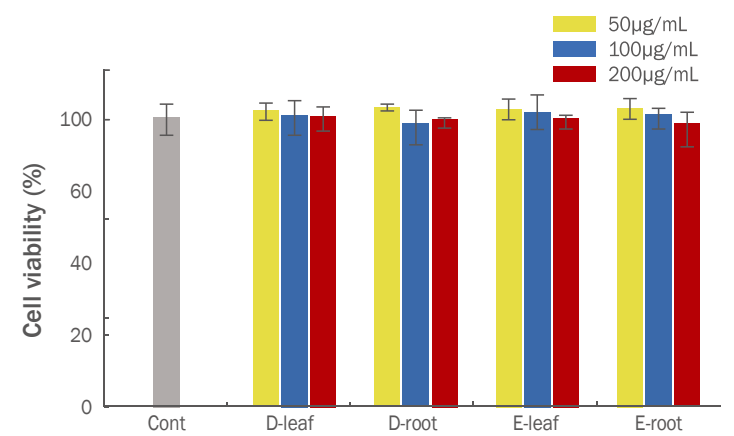

Figure 1. Cell viability of freeze dried A. hookeri extracts (by MTT assay).

A. hookeri extracts were treated with different concentrations (50, 100 , and $200 \mu \mathrm{g} / \mathrm{mL}$ ) in RAW 264.7 cells. Data are presented as mean $\pm \mathrm{SD}(\mathrm{n}=3)$. A. hookeri, Allium hookeri; D-leaf, distilled water extract of $A$. hookeri leaf; D-root, distilled water extract of A. hookeri leaf; E-leaf, $99 \%(\mathrm{v} / \mathrm{v})$ ethanol extract of $A$. hookeri root; E-root, $99 \%(\mathrm{v} / \mathrm{v})$ ethanol extract of $A$. hookeri root; MTT, 3-(4,5-dimethylthiazol-2-yl)-2,5-Diphenyltetra-zolium bromide; SD, standard daviation.

삼채 잎 $(91.73 \mathrm{~g} / 100 \mathrm{~g})$ 의 수분함량이 삼채 뿌리 $(86.13 \mathrm{~g} / 100$ $\mathrm{g})$ 에 비해 다소 높았다. 조회분함량의 경우도 잎 $(1.37 \mathrm{~g} / 100 \mathrm{~g})$ 이 뿌리 $(0.67 \mathrm{~g} / 100 \mathrm{~g})$ 에 비해 약 2 배 정도 높았다. 단백질함량도 잎 $(1.93 \mathrm{~g} / 100 \mathrm{~g})$ 이 뿌리 $(1.10 \mathrm{~g} / 100 \mathrm{~g})$ 에 비해 높았다. 지방함량 도 잎 $(0.17 \mathrm{~g} / 100 \mathrm{~g})$ 이 뿌리 $(0.07 \mathrm{~g} / 100 \mathrm{~g})$ 에 비해 높았다. 탄수 화물함량의 경우는 잎 $(4.80 \mathrm{~g} / 100 \mathrm{~g})$ 에 비해 뿌리(12.03 g/100 $\mathrm{g})$ 가 약 2.6 배 정도 높은 것으로 분석되어 다른 성분과는 상반된 결과를 보였다.

\section{2. 황 함량}

유황은 독특한 해독작용으로 인해 우수한 생리활성 효과를 지 니고 있으며, 만성질환 예방을 위한 소재로 많은 관심을 받고 있 다(Kwon et al., 2013; Hovius et al., 2005).

본 연구에서는 삼채의 잎과 뿌리에 함유되어 있는 황 함량을 분 석하여 Table 1에 제시하였다.

삼채 잎에는 황이 $9.90 \mathrm{mg} / 100 \mathrm{~g}$, 삼채 뿌리에는 26.54 $\mathrm{mg} / 100 \mathrm{~g}$ 으로 잎에 비해 뿌리에 약 2.7 배 더 많은 양의 황이 함 유되어 있었다. 본 연구 측정 수치와는 차이가 있으나, Kang et al. (2012)은 Allium 속 식물 중 하나인 마늘종(발효)과 삼채를 비 교하였을 때, 서로 비슷한 수준의 황을 함유하고 있었다고 보고하 였고, Park \& Yoon (2014)은 미얀마산(470.34 mg/100 g)에 비 해 국내산 $(711.15 \mathrm{mg} / 100 \mathrm{~g})$ 에 더 많은 황이 함유되어 있다고 보고하여, 황 함량이 우수한 국내산 삼채는 Allium 속 식물 대체 소재로서 가능성이 있다고 사료된다.

\section{3. 안전성 및 생리활성 평가}

1) MTT assay 


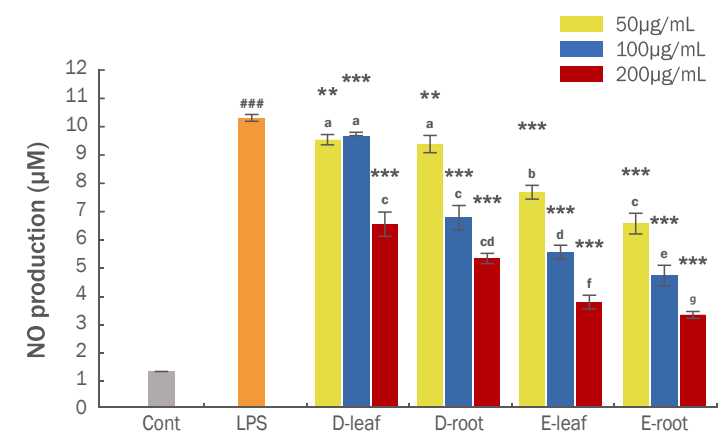

Figure 2. Suppressive effect of freeze dried $A$. hookeri extracts on NO production in LPS $(1 \mu \mathrm{g} / \mathrm{mL})$-induced RAW 264.7 cells.

A. hookeri extract treatments were applied at different concentrations $(50,100$, and $200 \mu \mathrm{g} / \mathrm{mL})$. Data are presented as mean $\pm S D(n=3)$. Means with different letters $(a-d)$ in the same column are significantly different at $p>0.05$ by Duncan's multiple range test. ${ }^{*} p<0.05,{ }^{* * *} p<0.001$ compared with LPS. ${ }^{\# \#} p<0.001$ compared with control. NO, nitric oxide; LPS, lipopolysaccharide; $A$. hookeri, Allium hookeri; D-leaf, distilled water extract of $A$. hookeri leaf; D-root, distilled water extract of $A$. hookeri root,; E-leaf, 99\% $(\mathrm{v} / \mathrm{v})$ ethanol extract of $A$. hookeri leaf; E-root, $99 \%(\mathrm{v} / \mathrm{v})$ ethanol extract of $A$. hookeri root; SD, standard deviation.

삼채 잎과 뿌리 용매별 추출물(열수: D-leaf, D-root, 에탄올: E-leaf, E-root)의 50, 100 및 $200 \mu \mathrm{g} / \mathrm{mL}$ 농도에서 세포독성 을 측정한 결과는 Figure 1에 제시된 바와 같다.

용매별 부위 추출물을 RAW 264.7 세포에 농도별로 처리한 결 과 모든 시료에서 최고 농도인 $200 \mu \mathrm{g} / \mathrm{mL}$ 에서도 $97 \%$ 이상의 생 존율을 나타내어 모든 농도에서 안전함을 확인하였다.

\section{2) $\mathrm{NO}$ 생성량}

그람음성세균의 내독소로 알려진 LPS를 대식세포에 처리하게 되면 많은 $\mathrm{NO}$ 를 형성하며 이에 의한 세포 독성은 $\mathrm{IL}-1 \beta, \mathrm{TNF}-\alpha$ 등과 같은 암 발생인자 및 염증유발인자를 방출하여 병리적인 반 응을 일으킨다(Posadas et al., 2000). 생성된 NO의 지속적 과발 현은 일부에서는 암 발생 등의 질환을 유도하고, 점막손상을 촉진
하기도 한다(Palmer et al., 1988).

본 연구에서는 대식세포인 RAW 264.7 세포에 LPS로 염증반 응을 유도시켜 삼채 잎과 뿌리 용매별 추출물을 각각 50, 100 및 $200 \mu \mathrm{g} / \mathrm{mL}$ 농도에서 $\mathrm{NO}$ 저해 활성을 측정 후 Figure 2에 제시 하였다.

RAW 264.7세포에 LPS을 처리하여 NO 생성량을 측정한 결 과, D-leaf의 경우는 $200 \mu \mathrm{g} / \mathrm{mL}$ 농도에서 $6.59 \pm 0.12 \mu \mathrm{M}$ 로 낮아져 가장 높은 저해 효과를 보였다. D-root의 경우는 $50 \mu \mathrm{g} /$ $\mathrm{mL}$ 농도에서 $9.70 \pm 0.20 \mu \mathrm{M}, 100 \mu \mathrm{g} / \mathrm{mL}$ 농도에서 $6.76 \pm 0.25$ $\mu \mathrm{M}, 200 \mu \mathrm{g} / \mathrm{mL}$ 농도에서 $5.88 \pm 0.11 \mu \mathrm{M}$ 로 농도 의존적으로 저해 활성이 높게 나타났다. E-leaf 경우 또한 농도별로 $7.90 \pm$ $0.21 \mu \mathrm{M}, 5.58 \pm 0.27 \mu \mathrm{M}, 4.09 \pm 0.12 \mu \mathrm{M}$ 로 농도 의존적으로 저해 활성이 높게 나타났다. E-root의 경우는 $50 \mu \mathrm{g} / \mathrm{mL}$ 농도에 서 $6.33 \pm 0.12 \mu \mathrm{M}, 100 \mu \mathrm{g} / \mathrm{mL}$ 농도에서 $4.69 \pm 0.15 \mu \mathrm{M}, 200$ $\mu \mathrm{g} / \mathrm{mL}$ 농도에서 $3.59 \pm 0.19 \mu \mathrm{M}$ 로 4 가지 시료 중 저해 효과가 가장 우수하였다. 확인된 열수 및 에탄올 추출물의 NO 생성억제 능을 토대로 판단할 때 삼채의 항염증 효과가 기대된다 하겠다.

추출 용매에 따른 효과는 에탄올 추출이 열수 추출에 비해 보다 효과적이었으며, 부위별 비교시에는 잎에 비해 뿌리의 NO 저해 활성이 보다 큰 것으로 분석되었다.

이는 잎에 비해 뿌리에 상대적으로 많이 함유된 황 성분이 $\mathrm{NO}$ 저해 활성에 영양을 미친 결과로 여겨진다(Table 1).

\section{3) 항산화능}

삼채 잎과 뿌리 용매별 추출물의 총 폴리페놀 함량과 총 플라보 노이드 함량은 Table 2 에 나타내었다.

총 폴리페놀 함량의 경우, D-leaf과 E-leaf은 각각 $131.12 \pm$ $2.08 \mathrm{mg} \mathrm{TAE} / 100 \mathrm{~g}, 131.01 \pm 2.17 \mathrm{mg} \mathrm{TAE} / 100 \mathrm{~g}$ 로 잎의 경 우 용매에 따른 차이는 없었다. 뿌리의 경우 $87.52 \pm 0.98 \mathrm{mg}$ $\mathrm{TAE} / 100 \mathrm{~g}$ 과 $112.23 \pm 1.06 \mathrm{mg} \mathrm{TAE} / 100 \mathrm{~g}$ 으로 에탄올 추출 물의 폴리페놀 함량이 높게 나타났다. Won et al. (2013)의 연 구에 의하면 삼채 뿌리에는 $95.70 \mathrm{mg} \mathrm{TAE} / 100 \mathrm{~g}$, 삼채 잎에는

Table 1. Proximate compositions of Allium hookeri (leaf and root)

\begin{tabular}{lcr}
\hline Composition & \multicolumn{2}{c}{ Allium hookeri (g/100 g, wet weight) } \\
Moisture & $91.73 \pm 0.75^{* * *}$ & \multicolumn{1}{c}{ Root } \\
\cline { 2 - 2 } Crude ash & $1.37 \pm 0.06^{* * *}$ & $0.67 \pm 0.06$ \\
Crude protein & $1.93 \pm 0.06^{* * *}$ & $1.10 \pm 0.10$ \\
Crude fat & $0.17 \pm 0.06^{\mathrm{NS}}$ & $0.07 \pm 0.06$ \\
Carbohydrate ${ }^{1)}$ & $4.80 \pm 0.20^{* * *}$ & $12.03 \pm 0.15$ \\
Sulfur & $9.90 \pm 0.58^{* * *}$ & $26.54 \pm 0.99$ \\
\hline
\end{tabular}

${ }^{1)}$ Carbohydrate=100-(moisture+crude protein+crude fat+crude ash).

${ }^{2)}$ All values are expressed as mean \pm standard deviation of triplicate determinations.

Ns , Not significant; ${ }^{* * *} p<0.001$ significant difference between leaf and root by Student's $t$-test. 
$120.98 \mathrm{mg}$ TAE$/ 100 \mathrm{~g}$, 부추에는 $220.98 \mathrm{mg} \mathrm{TAE} / 100 \mathrm{~g}$, 파에 는 $69.83 \mathrm{mg} \mathrm{TAE} / 100 \mathrm{~g}$ 의 폴리페놀성분이 함유되어 있다고 보 고한 바 있는데 본 연구 결과도 이와 비슷한 수준의 결과를 나타 내었다.

총 플라보노이드 함량의 경우, $21.25 \pm 0.16 \mathrm{mg} \mathrm{QE} / 100 \mathrm{~g}$ 의 D-leaf가 가장 높았으며, E-root (15.44 $0.17 \mathrm{mg} \mathrm{QE} / 100 \mathrm{~g})$,

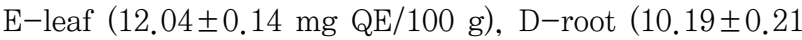

$\mathrm{mg} \mathrm{QE} / 100 \mathrm{~g})$ 순으로 함량이 높게 나타났다.

삼채 잎과 뿌리 용매별 추출물의 항산화능 측정 결과는 Table 3 에 제시하였다.

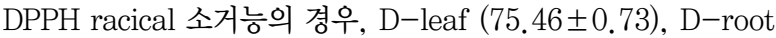
(27.19 \pm 0.26$)$, E-leaf $(63.87 \pm 0.79)$, E-root $(65.26 \pm 0.61)$ 으로 D-leaf의 소거능이 가장 높았으며, 에탄올 추출물은 부위별 소거능 차이가 나타나지 않았다.

Table 2. Total polyphenol and flavonoid contents of freeze dried A. hookeri extracts

\begin{tabular}{ccc}
\hline Sample & Total polyphenol content (mg TAE/100 g) & Total flavonoids content (mg RE/100 g) \\
D-leaf & $131.12 \pm 2.08^{1 / \mathrm{a} 2)}$ & $21.25 \pm 0.16^{\mathrm{a}}$ \\
D-root & $87.52 \pm 0.98^{\mathrm{c}}$ & $10.19 \pm 0.21^{\mathrm{d}}$ \\
E-leaf & $131.01 \pm 2.17^{\mathrm{a}}$ & $12.04 \pm 0.14^{\mathrm{c}}$ \\
E-root & $112.23 \pm 1.06^{\mathrm{b}}$ & $15.44 \pm 0.17^{\mathrm{b}}$ \\
\hline
\end{tabular}

A. hookeri; Allium hookeri; D-leaf, distilled water extract of $A$. hookeri D-leaf; D-root, distilled water extract of $A$. hookeri root; E-leaf, 99\% (v/v) ethanol extract of $A$. hookeri leaf; E-root, $99 \%(\mathrm{~V} / \mathrm{v})$ ethanol extract of $A$. hookeri root; TAE, tannic acid equivalent; RE, rutin equivalent.

${ }^{1)}$ All values are expressed as mean \pm standard deviation of triplicate determinations.

${ }^{2}$ Means with different letters $(\mathrm{a}-\mathrm{d})$ in the same column are significantly different at $p<0.05$ by Duncan's multiple range test.

Table 3. DPPH radical scavenging activity and ABTS radical scavenging activity of freeze dried A. hookeri extracts

\begin{tabular}{ccc}
\hline Sample & DPPH radical scavenging activity & ABTS radical scavenging activity \\
D-leaf & $75.46 \pm 0.73^{1 / \mathrm{a} 2)}$ & $97.17 \pm 0.77^{\mathrm{a}}$ \\
D-root & $27.19 \pm 0.26^{\mathrm{c}}$ & $57.12 \pm 0.52^{\mathrm{c}}$ \\
E-leaf & $63.87 \pm 0.79^{\mathrm{b}}$ & $84.17 \pm 0.74^{\mathrm{b}}$ \\
E-root & $65.26 \pm 0.61^{\mathrm{b}}$ & $85.23 \pm 0.85^{\mathrm{b}}$ \\
\hline
\end{tabular}

A. hookeri; Allium hookeri; D-leaf, distilled water extract of $A$. hookeri leaf; D-root, distilled water extract of $A$. hookeri root; E-leaf, $99 \%$ (v/v) ethanol extract of $A$. hookeri leaf; E-root, 99\% (v/v) ethanol extract of $A$. hookeri root; DPPH, 1,1-diphenyl-2-picrylhy drazyl; ABTS, 2,2'-azino-bis3-ethylbenzo-thiazoline-6-sulfonic acid.

${ }^{1}$ All values are expressed as mean \pm standard deviation of triplicate determinations.

${ }^{2)}$ Means with different letters $(\mathrm{a}-\mathrm{c})$ in the same column are significantly different at $p<0.05$ by Duncan's multiple range test.

Table 4. Correlation coefficients between functional materials and biological activities of $\boldsymbol{A}$. hookeri extracts

\begin{tabular}{lccc}
\hline Variables & NO production & $\begin{array}{c}\text { DPPH radical scavenging } \\
\text { activity }\end{array}$ & $\begin{array}{c}\text { ABTS radical scavenging } \\
\text { activity }\end{array}$ \\
Total polypenol & $-0.994^{* *}$ & $0.969^{* *}$ & $0.990^{* *}$ \\
Total flavonoid & $-0.999^{* *}$ & $0.994^{* *}$ & $0.996^{* *}$ \\
Sulfur & $-0.823^{* *}$ & $0.805^{* *}$ & $0.852^{* *}$ \\
\hline
\end{tabular}

${ }^{* *}$ Correlation is significant at the $p<0.01$ level; A. hookeri; Allium hookeri; NO, nitric oxide; DPPH, 1,1-diphenyl-2-picrylhy drazyl; ABTS, 2,2'-azinobis-3-ethylbenzo-thiazoline-6-sulfonic acid.

Table 5. Correlation coefficients between functional materials and biological activities for $99 \%$ ethanol extract of $\boldsymbol{A}$. hookeri

\begin{tabular}{|c|c|c|c|}
\hline Variables & NO production & $\begin{array}{l}\text { DPPH radical scavenging } \\
\text { activity }\end{array}$ & $\begin{array}{c}\text { ABTS radical scavenging } \\
\text { activity }\end{array}$ \\
\hline Total polypenol & $-0.950^{* *}$ & $0.961^{* *}$ & $0.944^{* *}$ \\
\hline Total flavonoid & $-0.936^{* *}$ & $0.921^{* *}$ & $0.958^{* *}$ \\
\hline Sulfur & $-0.943^{* *}$ & $0.925^{* *}$ & $0.980^{* *}$ \\
\hline
\end{tabular}

${ }^{* *}$ Correlation is significant at the $p<0.01$ level; A. hookeri; Allium hookeri; NO, nitric oxide; DPPH, 1,1-diphenyl-2-picrylhy drazyl; ABTS, 2,2'-azinobis-3-ethylbenzo-thiazoline-6-sulfonic acid. 


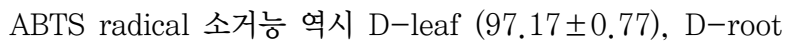

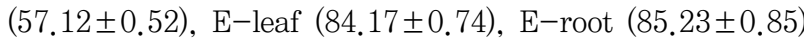
로 $\mathrm{DPPH}$ radical 소거능과 같이 D-leaf의 소거능이 가장 높았 고, 에탄올 추출물은 부위별 소거능 차이가 나타나지 않았으며, D-root의 소거능이 가장 낮게 나타났다.

이와 같은 결과는 삼채의 열수 뿌리 추출물 보다 잎 추출물에 서 총 폴리페놀 함량이 높았기 때문이라 생각된다. Kang et al. (1996)는 황 함유 채소의 DPPH 라디컬 소거능은 페놀성 화합물 과 서로 밀접한 관계가 있다고 보고 하였는데, 본 연구에서도 폴 리페놀 함량과 radical 소거능의 경향성이 같게 나타나 위의 연구 결과에서도 그와 같은 사실을 확인할 수 있었다.

\section{3. 삼채의 생리활성물질과 생리활성 간의 상관관계}

삼채 잎과 뿌리 용매별 추출물 시료들의 생리활성 물질과 생리 활성 간의 상관관계를 분석하여 Table 4 와 5 에 제시하였다.

삼채 열수 추출물의 경우, NO 생성량은 total polyphenol 함 량과 -0.994 , total flavonoid 함량과는 -0.999 , 황 함량과 는 -0.823 의 음의 상관관계를 나타냈다. $\mathrm{DPPH}$ 라디컬 소거능 은 total polyphenol 함량과는 0.969 , total flavonoid 함량과는 0.994 , 황 함량과는 0.805 의 양의 상관관계를 보였다. ABRTS 라 디컬 소거능은 total polyphenol 함량과는 0.990, total flavonoid 함량과는 0.996 , 황 함량과는 0.852 의 양의 상관관계를 보였다.

삼채 에탄올 추출물의 경우도 열수 추출물과 마찬가지로 NO 생 성량은 total polyphenol 함량과 -0.950 , total flavonoid 함량 과 -0.936 , 황 함량과 -0.943 의 높은 음의 상관관계를 보였다. 삼 $\mathrm{DPPH}$ 라디컬 소거능은 total polyphenol 함량과 0.961, total flavonoid 함량과 0.921, 황 함량과 0.925의 높은 양의 상관관 계를 보였다. ABRTS 라디컬 소거능은 total polyphenol 함량과 0.944 , total flavonoid 함량과 0.958 , 황 함량과 0.980 의 높은 양의 상관관계를 보였다.

이러한 결과로 미루어 볼 때 열수와 에탄올 추출 시료 모두 삼 채에 포함되어 있는 항산화물질과 황은 $\mathrm{NO}$ 생성은 억제, $\mathrm{DPPH}$ 라디컬 소거능과 ABTS 라디컬 소거능은 향상시키는 역할을 한 것으로 생각된다.

\section{Conclusion}

본 연구에서는 삼채를 잎과 뿌리로 분리하여 일반성분 및 황 함 량을 측정하였고, 안전성과 생리활성 측정을 위해서 삼채(잎과 뿌 리)를 동결건조 후 용매별(열수, 에탄올)로 추출하여 안전성(MTT assay)과 생리활성(항염증과 항산화)을 분석하였다.

삼채(잎과 뿌리)의 일반성분을 분석한 결과, 삼채 잎에 뿌리에
비해 더 많은 일반성분(수분, 단백질, 조회분, 지방)이 함유되어 있 었다. 다만, 탄수화물만이 잎에 비해 뿌리에 더 많이 함유되어 있 었다.

황은 뿌리 $(26.54 \mathrm{mg} / 100 \mathrm{~g})$ 가 잎 $(9.90 \mathrm{mg} / 100 \mathrm{~g})$ 에 비해 약 2.7배 정도 많이 함유하고 있었다.

삼채(잎과 뿌리, $\mathrm{DW}, \mathrm{EtOH}$ 추출물 시료)에 대한 안전성을 MTT assay로 알아본 결과, 50,100 및 $200 \mu \mathrm{g} / \mathrm{mL}$ 농도에서 $97 \%$ 이상의 생존율을 나타내어 삼채가 안전한 소재임이 증명되었다.

50,100 및 $200 \mu \mathrm{g} / \mathrm{mL}$ 농도의 삼채의 잎과 뿌리에 대한 열수 및 에탄올 추출 시료에 대한 $\mathrm{NO}$ 저해 활성을 측정 결과, 에탄올 뿌리 추출 시료(EtOH-root)에서 가장 높은 저해 효과가 나타났 다.

항산화능을 알아본 결과, free radical 소거능(DPPH, ABTS)은 삼채 잎 에탄올 추출시료에서 가장 높게 나타났다.

삼채의 용매별 추출물(열수, 에탄올)별로 활성물질과 생리활성 간의 상관관계를 분석한 결과, 열수 추출물과, 에탄올 추출물 모 두 total polyphenol, total flavonoid, 황 함량 등 생리활성물질 과 $\mathrm{NO}$ 생성량, $\mathrm{DPPH}$ 라디컬, $\mathrm{ABTS}$ 라디컬 소거능 등의 생리활 성 간에 모두 0.8 이상의 높은 상관관계가 있는 것으로 분석되었 다.

\section{Author's contribution}

JUK as the first author, collected Allium hookeri samples focusing on the study design of the messenger, and carried out all the experiments in the paper herself. The second author, AJK, was responsible for reviewing the experimental design in detail and correcting the errors directly. MJK, a messenger, personally conducted and accepted the research and design supervision of this paper. All authors read and approved the final manuscript.

\section{Author details}

Ji-Yun Kim (Graduate student), Department of Alternative Medicine, Kyonggi University, 24, Kyonggidaero-9 gil, Seodaemun-gu, Seoul 03746 Korea; AeJung Kim (Professor), Department of Nutrition Therapy, The Graduate School of Alternative Medicine, Kyonggi University, 63, Kyonggidae-ro-9 gil, Seodaemun-gu, Seoul 03752 Korea; Min-Ju Kim (Visiting Professor), Nutrition Therapy, The Graduate School of Alternative Medicine, Kyonggi University, 63, Kyonggidae-ro-9 gil, Seodaemungu, Seoul 03752 Korea. 


\section{References}

Ahn OH, Choi SH, Kim SH, Ryu SO, Choi YM. A study on risk factors of metabolic Syndrome and health behaviors in a region: 2014 community health survey. Journal of the Korea Academia-Industrial Cooperation Society, 17: 218-225, 2016.

Ayam VS. Allium hookeri, Thw. Enum. a lesser known terrestrial perennial herb used as food and its ethnobotanical relevance in Manipur. African Journal of Food, Agriculture, Nutrition Development, 11: 53895412, 2011.

Bae GC, Bae DY. The anti-inflammatory effects of ethanol extract of Allium hookeri cultivated in South Korea. Korean Journal of Herbology, 27: 55-61, 2012.

Cheon SY, Kim KH, Yook HS. Quality characteristics of wet noodles with Allium hookeri powder. Journal of the Korean Society of Food Science and Nutrition, 45: 8490, 2016.

Choe Y, Choe TB. Melanogenesis inhibitory effects of Allium hookeri extract in B16F10 mouse melanoma cell. Asian Journal of Beauty and Cosmetology, 12: 163-168, 2014.

Choi, HY, Kim GH. Inhibitory effects of Allium sacculiferun Max. methanol extracts on reactive oxygen species production and lipid accumulation during differentiation of 3T3-L 1 cells. Journal of Korean Society Food Science and Nutrition, 43: 822-828, 2014.

Davis WB. Determination of flavanones in citrus fruits. Analytical Chemistry, 19: 476-478, 1947.

Fellegrini N, Roberta KE, Min Y, Catherine RE. Screening of dietary carotenoids and carotenoid-rich fruit extracts for antioxidant activities applying 2,2'-azinobis(3ethylenebenzothiazoline-6-sulfonic acid) radical cation decolorization assay. Method in Enzymology, 299: 379389, 1999.

Hagenman GJ, Van Herwinen, Marcel HM, Schilderman, PAEL, Rhijinsburger EJ, Moonen C, Kleinjansns JC. Reducing effects of garlic consti-tuents on DNA adduct formation in human lymphocytes in vitro. Nutrition and Cancer, 27: 177-185, 1997.

Ham D, Jun S, Kang M, Shin S, Wie GA, Baik HW, Jung $H$. Association of total dietary antioxidant capacity with oxidative stress and metabolic makers among patients with metabolic syndrome. Journal of Nutrition and
Health, 50: 246-256, 2017.

Hong JK. A study on skin aging caused by free-radical and on efficacy of antioxidant vitamins. Asian Journal of Beauty and Cosmetology, 7: 51-62, 2009.

Hovius $\mathrm{MH}$, Goldman IL, Parkin KL. Flavor precursor [S-alk(en)yl-L-cysteine sulfoxide] concentration and composition in onion plant organs and predictability of field white rot reaction of onions. Journal of the American Society for Horticultural Science, 130: 196202, 2005.

Horwitz W, Latimer GW. Official methods of analysis of AOAC international (18th ed.). AOAC International, Gaithersburg, pp114-118, 2005.

Ji NR, Park KY. Stress-induced biphasic ethylene and ROS biosynthesis are synergistically interacted in cell damage. Journal of Plant Biotechnology, 38: 22-29, 2011.

Jung YH, Han JS, Kim AJ. Quality evaluation and antioxidant activity of inner beauty tea prepared from roasted lotus root and burdock. Asian Journal of Beauty and Cosmetology, 17: 235-245, 2019.

Kang MJ, Yoon HS, Shin JH. Chemical properties and biological activity of garlic (Allium sativum L.) shoots. Journal of Agriculture \& Life Science, 46: 129-139, 2012.

Kang YH, Park YK, Lee GD. The nitrite scavenging and electron donating ability of phenolic compounds. Korean Journal of Food Science and Technology, 28: 232-239, 1996.

Kim CH, Lee MA, Kim TW, Jang JY, Kim HJ. Anti-inflammatory effect of Allium hookeri root methanol extract in LPS induced RAW264.7 cells. Journal of the Korean Society of Food Science and Nutrition, 41: 1645-1648, 2012.

Kim JH, Lee YB, Han SY, Kim SJ, Hwang IH, Kim DK. Antioxidant activity of Helianthus tuberosus L. flower in Caenorhabditis elegans. Korean Journal of Pharmacognosy, 50: 96-101, 2019.

Kwon E, Ryu D, Surh J. Quality characteristics of onions applied with methylsulfonylmethane (MSM) during cultivation. Korean Journal of Food Science and Technology, 45: 213-220, 2013.

Lee MA, Choi HJ, Kang JS, Choi YW, Joo WH. Antioxidant activities of the solvent extracts from Tetragonia tetragonioides. Journal of Life Science, 18: 220-227, 
2008.

Masaki H, Sakaki S, Atsumi T, Sakurai H. Active oxygen scavenging activity of plants extracts. Biological and Pharmaceutical Bulletin, 18: 162-166, 1995.

Min JH, Baik YS, Jang WC, Jeong CH. A study on etiologic factors in modern society. The Journal of Korean Medical Classics, 24: 161-181, 2011.

Naik GH, Priyadarsini KI, Naik DB, Gangabhagirathi R, Mohan H. Studies on the aqueous extract of Terminalia chebula as a potent antioxidant and a probable radioprotector. Phytomedicine, 11: 530-538, 2004.

Park JY, Yoon KY. Comparison of the nutrient composition and quality of the root of Allium hookeri grown in Korea and Myanmar. Korea Journal of Food Science and Technology, 46: 544-548, 2014.

Palmer RM, Ashton DS, Moncada,S. Vascular endothelial cells synthesize nitric oxide from L-arginine. Nature, 333: 664-666, 1988.

Posadas I, Tereencio MC, Guillen I, Ferrandiz ML, Coloma
J, Paya M, Alcaraz MJ. Co-regulation between cyclooxygenase- 2 and inducible nitric oxide syn-thase expression in the time-course of murine inflammation. Naunyn Schmiedeberg's Archives of Pharmacology. 361: 98-106, 2000.

Won JY, Yoo YC, Kang EJ, Yang H, Kim GH, Seong BJ, Kim SI, Han SH, Lee SS, Lee KS. Chemical components, DPPH radical scavenging activity and inhibitory effects on nitric oxide production in Allium hookeri cultivated under open field and greenhouse conditions. Journal of Korea Society of Food Science and Nutrition, 42: 1351-1356, 2013.

Yun ME, Lee YS, Lee YJ, Park YM, Park SN. Antimicrobial, antioxidant and cellular protective effects of Houttuynia cordata extract and fraction. Applied Chemistry for Engineering, 29: 452-460, 2018. 


\section{국문초록}

\section{삼채의 안전성 및 생리활성평가}

김지윤 ${ }^{1}$, 김애정 ${ }^{2}$, 김민주 ${ }^{2 *}$

${ }^{1}$ 경기대학교 대체의학과, 서울, 한국

${ }^{2}$ 경기대학교 대체의학대학원 식품치료전공, 서울, 한국

목적: 본 연구는 삼채의 안전성을 평가 하고 생리활성을 측정하기 위해 수행되었다. 방법: 안전성 평가를 위해서 삼채 잎과 뿌리 추 출물시료(DW, EtOH)로 MTT assay를 측정하였고, 삼채 잎과 뿌리 시료로는 일반성분과 황 함량 측정하였다. 그리고 항염증효과 와 항산화 활성을 측정하고자 삼채 잎과 뿌리 추출물시료 $(\mathrm{DW}, \mathrm{EtOH})$ 를 사용하여 $\mathrm{NO}$ 생성량, 총 폴리페놀, 플라보노이드 함량 및 프리라디컬 소거능(DPPH, $\mathrm{ABTS})$ 을 각각 측정하였다. 또한, 삼채의 활성 물질과 생리활성(항염증과 항산화)간의 상관성을 알아보 고자 상관관계를 구하였다. 결과: MTT assay 결과, $50,100,200 \mu \mathrm{g} / \mathrm{mL}$ 농도에서 $97 \%$ 이상의 생존율을 보여 삼채 잎과 뿌리 모두 안전한 소재임이 규명되었다. 탄수화물 함량을 제외한 모든 일반성분 함량이 삼채 잎에서 가장 높게 나타났다. 황 함량은 삼채 뿌 리에서 가장 많은 함량이 나타났다. NO 생성 억제 효과는 삼채 뿌리 에탄올 추출시료에서 가장 높게 나타났다. 프리라디컬 소거능 (DPPH, ABTS)은 삼채 잎 에탄올 추출시료에서 가장 높게 나타났다. 결론: 삼채의 활성물질과 생리활성 간의 상관계수로 미루어 보 아, 삼채에 함유되어 있는 활성물질이 $\mathrm{NO}$ 생성을 억제시키고 항산화 활성을 발현시키는데 중요한 작용을 했음을 알 수 있었다.

핵심어: 삼채, 황, 세포생존율, 항산화, 산화질소생성

\section{참고문헌}

강민정, 윤환식, 신정혜. 마늘종의 화학적 특성 및 생리활성. 농업생명과학연구, 43: 129-139, 2012.

강윤한, 박용곤, 이기동. 페놀성 화합물의 아질산염 소거 및 전자공여 작용. 한국식품과학회지, 28: 232-239, 1996.

김창현, 이미애, 김태운, 장자영, 김현주. 삼채 뿌리 메탄올 추출물이 LPS가 유도된 RAW264. 7 세포에 대한 항염증 효과.

한국식품영양과학회지, 41: 1645-1648, 2012.

김준형, 이예빈, 한선여, 김수진, 황인현, 김대근. 돼지감자꽃의 예쁜꼬마선충 내의 항산화 효과. 생약학회지, $50: 96-$ 101, 2019.

권은진, 류다연, 서정희. 양파 재배 중 식이유황 methylsulfonlymethane 처리가 양파의 품질 특성에 미치는 영향. 한국식

품과학회지, 45: 213-220, 2013.

민진하, 백유상, 장우창, 정창현. 현대사회의 발병인자에 대한 고찰. 대한한의학원전학회지, 24: 161-181, 2011.

박주영, 윤경영. 국내 및 미얀마에서 재배된 삼채뿌리의 영양성분 및 품질특성 비교. 한국식품과학회지, 46: 544-548,

2014

배기춘, 배대열. 국내산 삼채 에탄올 추출물의 항염증 효과. 대한본초학회지, 27: 55-61, 2012.

안옥희, 최성희, 김서현, 류시옥, 최영미. 일 지역 대사증후군 위험인자와 건강행태에 관한 연구: 2014 지역사회건강조사.

한국산학기술학회논문지, 17: 218-225, 2016.

이민아, 최혜정, 강점순, 최영환, 주우홍. 번행초 추출물의 항산화 활성. 생명과학회지, 18: 220-227, 2008.

윤믿음, 이예슬, 이윤주, 박영민, 박수남. 어성초 추출물 및 분획물의 항균, 항산화 및 세포보호활성. 공업화학, 29: 452-

460, 2018.

원준연, 유영춘, 강은주, 양해, 김관후, 성봉재, 이가순. 노지 및 시설재배 삼채 뿌리 및 잎의 이화학 성분, $\mathrm{DPPH}$ 라디칼

소거능 및 Nitric Oxide 생성 억제효과. 한국식품영양과학회지, 42: 1351-1356, 2013.

정연희, 한정순, 김애정. 로스팅한 연근과 우엉을 이용한 이너 뷰티 차의 항산화 활성과 품질 평가. 아시안뷰티화장품학술 
지, 17: 235-245, 2019.

지나리, 박기영. 스트레스에 의한 식물세포 손상에서 Biphasic Reactive Oxygen Species (ROS) 와 Ethylene 생합성의 Synergism 효과. 식물생명공학회지, 38: 22-29, 2011.

천세영, 김경희, 육홍선. 삼채(Allium hookeri) 분말을 첨가한 생면의 품질 특성. 한국식품영양과학회지, 45: 84-90, 2016.

최연선, 최태부. B16F10 mouse melanoma 세포에서 삼채(Allium hookeri) 추출물의 멜라닌 형성 억제 효과에 관한 연 구. 아시안뷰티화장품학술지, 12: 163-168, 2014.

최혜영, 김건희. 참산부추(Allium sacculiferum Max.) 메탄올 추출물의 지방세포 내 ROS 생성 및 지질 축적 억제 효능. 한국식품영양과학회지, 43: 822-828, 2014.

함동우, 전신영, 강민지, 신상아, 위경애, 백현욱, 정효지. 대사증후군 환자 및 위험군의 식사 내 총 항산화능과 산화스트 레스 및 대사 지표의 연관성. 한국영양학회지, 50: 246-256, 2017.

홍재기. 활성산소에 의한 피부노화와 항산화비타민의 효능에 대한 이론적 고찰. 아시안뷰티화장품학술지, 7: 51-62, 2009. 


\section{中文摘要}

\section{宽叶非的安全性和理化活性}

金志潤1，金愛貞 ${ }^{2}$, 金玟珠 $^{2 *}$

1京畿大学代替医疗学科, 首尔, 韩国

2京畿大学代替医疗大学院食品治疗学科, 首尔, 韩国

目的：评估宽叶韭提取物的理化活性和安全性。方法：进行了宽叶韭提取物（叶和根, DW和EtOH）的MTT分 析，以评估安全性。关于一般成分的理化活性，分析了硫化合物（叶和根），抗炎作用和抗氧化剂活性（叶和 根, DW和EtOH），并测试了理化之间是否存在任何相关性物质以及自由基清除活性（DPPH和ABTS）。结果： 在MTT分析中，浓度分别为 $50 、 100$ 和 $200 \mu \mathrm{g} / \mathrm{mL}$ 的宽叶非提取物，细胞存活率 $97 \%$ 以上，表明它们是安全的。 宽叶非生叶中除碳水化合物外的所有一般组成成分均高于生根, 而硫含量最高。EtOH根提取物的NO抑制作用 最高。EtOH叶提取物的DPPH和ABTS自由基清除活性最高。结论: 理化物质活性（总多酚, 总黄酮和硫）与自 由基清除活性（DPPH和ABTS）相关，导致NO生成受到抑制，从而增强了自由基清除活性。

关键词: 宽叶非, 硫, MTT测定, 抗氧化活性, NO生成 
